This item was submitted to Loughborough's Research Repository by the author.

Items in Figshare are protected by copyright, with all rights reserved, unless otherwise indicated.

\title{
The electoral dynamics of human development
}

PLEASE CITE THE PUBLISHED VERSION

http://dx.doi.org/10.1080/00220388.2017.1288221

PUBLISHER

(c) Taylor \& Francis

VERSION

AM (Accepted Manuscript)

PUBLISHER STATEMENT

This work is made available according to the conditions of the Creative Commons Attribution-NonCommercialNoDerivatives 4.0 International (CC BY-NC-ND 4.0) licence. Full details of this licence are available at: https://creativecommons.org/licenses/by-nc-nd/4.0/

\section{LICENCE}

CC BY-NC-ND 4.0

\section{REPOSITORY RECORD}

Castro, Vitor, and Rodrigo Martins. 2019. "The Electoral Dynamics of Human Development”. figshare. https://hdl.handle.net/2134/24138. 


\title{
The Electoral Dynamics of Human Development ${ }^{*}$
}

\author{
Vítor Castro* \\ Loughborough University and NIPE, Portugal \\ Rodrigo Martins ${ }^{\star}$ \\ University of Coimbra and GEMF, Portugal
}

\begin{abstract}
This paper analyses the impact of elections, partisan and political support effects on the dynamics of human development in a panel of 82 countries over the period 1980-2013. A GMM estimator is employed and the results point out to the presence of an electoral cycle in the growth rate of human development. Majority governments also influence it, but no evidence is found regarding partisan effects. The electoral cycles have proved to be stronger in non-OECD countries, in countries with less frequent elections, with lower levels of income and human development, in presidential and non-plurality systems and in proportional representation regimes.
\end{abstract}

Keywords: Human development; Political cycles; Elections; Panel data models.

JEL classification: C33; D72; I31; O15.

\footnotetext{
* The authors acknowledge the helpful comments and suggestions from Toke Aidt and the participants at the 10th Annual Meeting of the Portuguese Economic Journal, University of Coimbra, Portugal, 1-3 July 2015. Vitor Castro also wishes to thank the financial support provided by the Portuguese Foundation for Science and Technology under the research grant SFRH/BSAB/113588/2015 (partially funded by COMPTE, QREN and FEDER). This paper was partially written while Vitor Castro was visiting the Faculty of Economics, University of Cambridge, UK. The author is grateful for the facilities provided by this University to develop his research. The data and Stata code used in this analysis is available upon request.

* School of Business and Economics, Loughborough University, Loughborough, Leicestershire LE11 3TU, UK.

University of Minho, Economic Policies Research Unit (NIPE), Campus of Gualtar, 4710-057 Braga, Portugal. Tel.: +44 (0)1509 222706; E-mail: V.M.Q.Castro@lboro.ac.uk

• Faculty of Economics, University of Coimbra, Av. Dias da Silva 165, 3004-512 Coimbra, Portugal. Group for Monetary and Fiscal Studies (GEMF), Av. Dias da Silva 165, 3004-512 Coimbra, Portugal. Tel.: +351239790543; E-mail: rodrigom@ fe.uc.pt
} 


\section{Introduction}

The existing literature on political cycles has typically focused on the economic policy activity of governments. It is assumed that policymakers have strong incentives to align policy measures with the timing of elections and/or with the electorate's partisan preferences. As such it is expected that the economy exhibits clear economic cycles that closely track the electoral calendar. One fundamental assumption behind all politico-economic models is that voters prefer those candidates that can deliver them greater well-being. However, behind this hypothesis there is another one very well-known across all areas of economics: when we improve agents' economic prosperity, we deliver them more well-being. This Maslow-based view of people's needs puts economic concerns before any others, considering that the financial well-being is the only necessary condition for general well-being but, nevertheless, recognizing that it is not a sufficient condition. More so in cases where people's basic economic needs are satisfied, like for most individuals in prosperous democracies.

Government turnover is another important feature for the consolidation of prosperous democracies. Therefore, elections and the uncertainty of remaining in office represent a big incentive for incumbents to implement measures that promote their re-election chances. There is no reason to think that they only implement measures targeting the economy. Instead it is safe to assume that they will target all aspects they think will benefit their chances of re-election. As such, effects of opportunistic manipulation in social dimensions are a possibility, thus intensifying the need to understand whether human development is also conditioned by political aspects like elections and the ideology of governments. It is well known that data about GDP, income, unemployment, inflation, public debt and other macroeconomic aggregates does not provide information about all the important preferences of their real beneficiaries. Economic agents frequently value achievements such as better education and health services, broader participation in economic, cultural and political activities of the local community, improvements in working conditions and security against crime and physical violence, that are not necessarily reflected in higher income, output growth or aggregated public accounts. Moreover, while the purpose and ultimate goal behind any policy intervention must be to contribute to a more efficient allocation of resources, the aim of the policymakers in office is to survive public 
scrutiny at the elections. To fulfil that objective they need to please voters, and this means that they must provide better public services (education, health, safety,..), implement measures to reduce inequality and unemployment, and to promote growth. These measures should have an important impact on the living standards of the population thus promoting not only economic growth but also human development.

Hence, it seems sensible to consider other dimensions of development, instead of simply looking at economic variables, to draw the complete picture of democracy's effect on people's lives. In this paper, we try to move closer to the idea that governments supply more than economic well-being in exchange for votes and try to find evidence that the political cycle is not limited to the economic dimension, and thus putting empirical research a step closer to the reality.

Contrary to economic growth, that is simply related to quantitative changes in a country's economy, economic development involves quantitative and qualitative changes in a country and reflects not only economic and technological progress but also social relations, health conditions, education standards, personal safety and social progress. It is a broader measure of key determinants of human well-being. However, defining and measuring economic development is not straightforward. Several alternatives have been developed to measure it combining a few indicators of economic development (Fleurbaey, 2009). The most commonly accepted is the Human Development Index (HDI), which was developed by the United Nations Development Program (UNDP) in 1990. This is a broad measure that covers multi-dimension aspects of economic development, especially, education, health and income (Sen, 1999).

This study represents a first attempt of exploring the electoral dynamics of well-being, taking the advantage of using a broad human development indicator that encompasses not only the economic, but also social dimensions of a society. This will allow us to answer the forgotten question of whether and how human development is affected by political motives and electoral calendars in both developed and developing countries. Although the linkage between elections/ideology and the social components of the HDI are mainly done through public expenditures we think that investigating the end result of politics on the outcome variable HDI is of particular interest. To proceed with this analysis, we use data over a panel of 82 countries 
during the period 1980-2013 to test for the presence of political cycles, partisanship, and government support effects on the growth rate of human development. A GMM estimator is employed in the empirical analysis and the results unveil the presence of political cycles in the human development: during election years human development tends to accelerate. Majority governments also exert a significant effect on it, but no evidence is found regarding partisan effects. Moreover, these political cycles are especially observed in developing countries, with lower income and lower levels of HDI, and in countries with less frequent elections. Additional evidence shows that they have become more intense in this millennium. Presidential and non-plurality systems and proportional representation regimes are also characterized by stronger political cycles.

This article is organized as follows. Section 2 presents a brief review of the relevant literature. Section 3 describes the data and presents the econometric model. The main results are presented and discussed in section 4. Some robustness checks are provided in section 5 and section 6 concludes.

\section{Literature review}

Measuring economic development and evaluating its behaviour to changes in economic, social, institutional and political variables has become an important task of several recent theoretical and empirical researches. Many studies have tried to construct measures of well-being. Fleurbaey (2009) summarizes three main approaches: adjusted GDP, happiness indices, and the Human Development Index.

The adjusted GDP approach is based on welfare economics and aims to derive indicators of change in social welfare focusing on the intertemporal dimension of social welfare (Dasgupta, 2001). In practice, this approach relies on capital stocks as the drivers of changes in the intertemporal well-being of individuals. However, although theoretically appealing, it suffers from practical implementation problems (difficulties of generating comparable measurements across countries) and conceptual weaknesses (it is based on the theory of revealed preference). The happiness approach - which is based on evidence from surveys on well-being (Frei and Stutzer, 2002) - also suffers from serious problems of comparability across time and space. 
The Human Development Index (HDI) has been considered a more consensual measure of social welfare. Indeed, the 1990 Human Development Report and the seminal research by Fukuda-Parr and Shiva-Kumar (2003) have set the stage for much of the subsequent investigation that followed. According to the Human Development Report (UNDP, 2014), this is a summary index (geometric mean) of three essential dimensions of human development: $(i)$ long and healthy life; (ii) access to knowledge and education; and (iii) decent and stable living standards. Ul Haq (1995) notices that it measures well-being and not just income by including both economic and social dimensions of well-being; additionally, its coverage and methodology is flexible enough to allow a measure of multi-dimensional well-being. Alkire (2007), Comim et al. (2008) and Molina and Purser (2010) also point out that the HDI allows for simple, replicable and comparable cross-country and within-country measures of human development.

The HDI also presents some limitations such as weighting different aspects of life in the same way for all individuals, difficulties in comparing countries by other factors like the quality of schools or dropout rates, and the fact of the index values range between 0 and 1 which may not well reflect the differences between countries. Nevertheless, its practical advantages over the alternatives make it preferable is most empirical applications. Nafziger (2012) considers it as a better, more complete and multifaceted measure of human development than any other indicator or index, being useful for the qualitative aspects of development. Several studies, in different fields, have used the HDI as a measure of economic development and to test how it reacts to changes in important economic, social and political variables. For example, Ranis et al. (2005) show that child mortality is highly correlated with HDI; Timmer and Akkus (2008) assess the gender determinants of long-term human development; Wolfers (2009) finds that income per capita is highly correlated with HDI ranking; ${ }^{1}$ Davis (2009) and Martins and Veiga (2014) analyzes the effects of government size and the composition of public expenditure on economic development.

This paper analyzes the existence of democracy related effects on the human development, with a special focus on the impact of elections and of government ideology. Due to the advantages discussed above, we use the HDI as the measure of choice to investigate the presence of politically induced development cycles. 
The analysis of political cycles has essentially focused on the economic sphere, i.e. variables like GDP, unemployment, inflation and other macroeconomic variables, along with fiscal and debt formation variables (see, Franzese (2002) for an encompassing survey). The political business cycles and partisan theories are the main theoretical frameworks that indicate how governments affect macroeconomic outcomes. The political business cycles theories (PBC) are divided into models that assume agents with adaptive expectations (Nordhaus, 1975) and more recent models that adopt rational expectations (Rogoff and Sibert, 1988; and Rogoff, 1990). The main implication of these models is that all politicians implement expansionary economic policies before elections with the objective of maximizing their electoral support and afterwards contractionary measures are required to correct the artificial unbalance generated previously. $^{2}$ If the objective of governments is to produce more economic well-being in order to generate more votes, we can easily extend the PBC theory to include social dimensions. Development features like better health and education along with other social protection and personal aspects of people's lives should improve near elections. Short-term policy shifts like increases in expenditures in these areas can generate the typical post electoral downturn after elections described by the theory. Studies like Blais and Nadeau (1992), Potrafke (2010), Enkelman and Leibrecht (2013) and Castro and Martins (2016) report the presence of PBC cycles in some welfare related expenditures. ${ }^{3}$ However, part of the development relies on structural policies, for which the post-electoral effect is hard to achieve. Nevertheless, we can assume that some structural non-economic shifts that take longer to come in effect can be timed by competent governments in order to produce at least some effects near elections.

Regular government turnover is an important feature for the consolidation of democracy. Hence, elections and the expectation of a change in the government can be an incentive for incumbents to invest in long-term measures that promote development and increase their chances of reelection.

Alternatively to the PBC theories, both the adaptive (Hibbs, 1977) and rational (Alesina, 1987, 1988; Alesina and Sachs, 1988) versions of the partisan theory view politicians as heterogeneous, arguing that different parties have different policy objectives, behaving, when in office, in a partisan manner. Left-wing parties are relatively more concerned with unemployment 
(growth) than with inflation, whereas right-wing parties are especially worried with inflation control. ${ }^{4}$ The effect of partisanship on the development of the welfare state has been widely debated and non-economic dimensions of State intervention like some welfare policies such as health, education and social protection have been considered (see Imbeau et. al. (2001) for a meta-analyses on the relationship between party ideology and government policies). Overall, the traditional assumption behind partisan effects is that left parties tend to promote the welfare intervention by the State, while right-wing governments are negatively correlated with State involvement in welfare.

Left governments are assumed to want more state presence in people's lives and are also bigger spenders than right-wing parties. Hence, they are expected to be better providers of education, health and social security. ${ }^{5}$ However, Wilensky (1976) claims that there is a process of cross national convergence regardless of ideological concerns, arguing the industrialized countries report similar welfare states as a consequence of their similar levels of economic performance.

Overall, the theoretical linkage between elections/ideology and the HDI is an indirect one. It is not reasonable to assume that governments manipulate the HDI directly for electoral purposes. Instead the relationship is mediated through policy, especially by public spending adjustments when it comes to social aspects. However, when dealing with social dimensions, the policies can be more than spending variations and include changes in the framework of the social dimension itself.

As far as we are concerned, the presence of political cycles has never been tested in any indicator of human development. Nevertheless, some aspects of the relationship between human development and political systems have been analysed. For example, Gassner et. al. (2006) found that countries that have proportional systems tend to enjoy higher levels of human development, when compared to those with majority systems. Also, Miller (2015) shows that the existence of elections in autocratic regimes matters for human development: autocratic regimes with legal multiparty elections seem to outperform regimes without elections with respect to a wide range of human development outcomes. 


\section{Data and model specification}

To analyse the presence of political cycles in the human development, we had annual data for the HDI regarding 182 sovereign states over the period 1980-2013. However, to be included in our final sample a country must have regular competitive elections over the relevant period. To choose which countries to include we used the Legislative and Executive Indices of Electoral Competitiveness from the Database of Political Institutions (DPI) which scores countries on a scale of 1 to 7 , and excluded those countries with a value lower than 6 . Adding to this, the presence of missing values for some variables, mainly for developing countries, made the number of available countries to 82 at most. ${ }^{6}$

To tackle the problem of estimating the proposed relationship, one alternative would be to do a first-stage examination of what impact political variables have on social spending (health, education, etc) and in a second-stage explore the effect of these spending adjustments on the HDI. This fits the idea that the relationship between elections/ideology and the HDI is mediated by public spending adjustments. Although this method depicts more accurately the reality of social outcomes, it might not be so successful regarding the economic dimension of the HDI. It also reduces significantly the number of available observations. For these reasons - and because our main goal is to analyze the end result of politics on the outcome variable HDI - we chose a single equation approach to portrait the relationship and introduce some relevant variables for economic activity that we believe help isolate the effect of political variables. The dependent variable used is the growth rate of the Human Development Index (HDI_gr). The HDI is a measure of the average achievement in key dimensions of human development, namely: (i) a long and healthy life; (ii) being knowledgeable; and (iii) a decent standard of living. This index is the geometric mean of normalized indices for each of those three dimensions. The data for those indices and HDI are provided by Human Development Report of the United Nations Development Programme (UNDP, 2014). ${ }^{7}$

The explanatory variables included in the baseline model are the lag of $H D I$ gr (to account for the persistence in the adjustment), the set of the political variables of interest and some economic, institutional and demographic controllers. The political variables are provided by the Database of Political Institutions 2012 and by the Comparative Political Data Set I 2013: 
- Elect_yr: a dummy variable that takes de value of 1 in the year of legislative elections; and 0 , otherwise.A positive sign is expected for its estimated coefficient, meaning that political cycles are present in the growth rate of Human Development.

- GovLeft: a dummy variable that takes de value of 1 when there is hegemony or dominance of left-wing parties in the cabinet; and 0 , otherwise (centre or right-wing parties). Our expectation is that left-wing governments are more concerned with Human Development than their centre or right-wing counterparts.

- GovMaj: a dummy variable that takes the value of 1 when a single party or coalition has majority in the parliament; and 0, otherwise. Majority governments have enough support to promote development measures; however, the power they have to favour their own agenda and interests may not be favourable to human development, so no clear sign is anticipated for the coefficient on this variable.

- GovCoal: a dummy variable that takes the value of 1 when a coalition government is in office, regardless of having majority or not; and 0 , otherwise. It is also difficult to anticipate a sign for its coefficient, as different interests may delay important measures or generate a consensus for the need of their implementation.

- MajCoal: a dummy variable that takes the value of 1 when a majority coalition government is in office; and 0, otherwise. It is equal to GovMaj*GovCoal. Once again, for the reasons indicated above, it is not easy to foresee the direction of its impact on $H D I \_g r$. However, this is another important political dimension to be considered in this analysis.

The additional set of variables includes controllers for the rating risk at economic, financial and political levels and for population growth. The data for the risk of rating variables comes from the International Country Risk Guide (ICRG) and the population data is obtained from the World Development Indicators. The variables are defined as follows: ${ }^{8}$

- EcoRating: the economic risk rating is obtained by a weighted average of information on GDP per head, real GDP growth, annual inflation, budget balance over GDP and current account over GDP. The aim of this index is to provide compiled information on the general economic environment, strengths and weaknesses. A higher value for this index 
represents a better and strength economic environment, which is expected to have a positive impact on human development. ${ }^{9}$

- FinRating: The financial risk rating index includes foreign debt as a percentage of GDP, foreign debt service as a percentage of exports of goods and services, current account as a percentage of exports of goods and services, net international liquidity as months of import cover and exchange rate stability. The aim of this risk rating is to provide a means of assessing a country's ability to pay its obligations and to finance its official, commercial, and trade debt obligations. We also expect that a better rating will mean higher development.

- PolRating: the political risk rating includes 12 weighted variables covering both political and social attributes. ${ }^{10}$ Its aim is to provide a means of assessing the political stability of the countries on a comparable basis. We conjecture that a better rating has a positive impact on human development.

- Pop_gr: growth rate of total population. As a high population growth brings an increased pressure on the management of natural resources and over the socio-economic relations, we believe that it may also be detrimental for the growth rate of human development.

The descriptive statistics for these and other related variables - that will be considered in some additional specifications/experiments - are reported in Table A.3 in Annex. To estimate the impact of those variables on the growth rate of the human development index, we consider the following dynamic panel data specification:

$$
H D I \_g r_{i t}=\alpha+\rho H D I \_g r_{i t-1}+\boldsymbol{\beta} \boldsymbol{P o l}_{i t}+\boldsymbol{\gamma} \boldsymbol{R a t i n g}_{i t}+\delta P o p \_g r_{i t}+\theta T_{i m} e_{t}+v_{i}+e_{i t}
$$

where $i=1, \ldots, 82$ and $t=1981, \ldots, 2013$. Pol and Rating represent, respectively, the vectors of the political and risk rating variables. The coefficient on the lag of the dependent variable $(\rho)$ measures its persistence. The vector $\boldsymbol{\beta}$ captures the impact of the electoral cycle, partisan and government support effects on HDI_gr, while the vector $\gamma$ assesses the effect of the economic, financial and political environment controllers. The impact of population growth is given by the coefficient $\delta$. Additionally, we also control for the passage of time by including the Time variable 
in the specification. Regarding the last components, $v_{i}$ is the individual effect of each country $i$, and $e_{i t}$ is the error term.

Given the presence of individual effects $v_{i}$, the model can be estimated assuming those effects as fixed or random. However, the lagged value of the dependent variable would be correlated with the error term, even if the latter is not serially correlated. This implies that OLS estimates (random or fixed effects) will be biased and inconsistent (Baltagi, 2008). Although the fixed effects (FE) estimator gains consistency as the number of time periods increases, the time-series dimension in this analysis might not be large enough $(T=33)$ for us to rely entirely on its estimates. ${ }^{11}$

The estimators that take into account that bias can be grouped into: $(i)$ bias-corrected estimators; and (ii) instrumental variables estimators. Bias-corrected estimators, like the one proposed by Bruno $(2005 \mathrm{a}, \mathrm{b})$ - the bias-corrected least squares dummy variable estimator (LSDVC) for dynamic panel data models - are suitable when the number of individuals $(N)$ is small (and $T$ is not large enough). Although $T$ is not large in this study, the number of individuals cannot be considered small $(N=82)$. Hence, this estimator may not be the most suitable procedure to solve the bias problem caused by the inclusion of the lag of the dependent variable in the list of regressors.

According to the large sample properties of the generalized method of moments (GMM), the dynamic estimator proposed by Arellano and Bond (1991) is adequate when there is a clear dominance of cross sections over time periods in the sample. This is what happens in our panel, which means that this estimator is a more appropriate procedure to solve the bias problem. Taking first differences of equation (1), levels of the explanatory variables can be used as instruments to avoid correlation between lagged dependent variable and the country-specific effects. ${ }^{12}$ Arellano and Bond (1991) also proposed a variant of the GMM estimator, namely the two-step estimator, which utilizes the estimated residuals in order to construct a consistent variance-covariance matrix of the moment conditions. Although the two-step estimator is asymptotically more efficient than the one-step estimator and relaxes the assumption of homoscedasticity, the efficiency gains are not that important even in the case of heteroscedastic errors. This result is supported by Judson and Owen (1999), who showed empirically that the 
one-step estimator outperforms the two-step estimator, especially when the number of time periods is relatively high $(T=30)$, which is the case in this study.

Arellano and Bover (1995) and Blundel and Bond (1998) suggest another GMM estimator with additional moment conditions. If they are valid, they will increase the efficiency of the estimators. This is known as the system GMM estimator, which combines the moment conditions of the model in first differences with those of the model in levels (differences are used as instruments for the level equations).However, if the orthogonality conditions for the first-difference equation are valid, but those for the level equation are not, then the system GMM may not be better than first-differences GMM. This can happen, for example, if the regressors used in the orthogonality conditions for the levels equation are correlated with the individual effects. Moreover, simulations suggest that the system GMM is not necessarily superior to the standard GMM in cases where the autoregressive parameter is below 0.8 and the time-series observations are relatively large (Blundell and Bond, 1998; Moshirian and Wu, 2012). This is what we observe in our data, so the estimator that seems to be more suitable for our empirical analysis is the one-step first-differences GMM estimator.

Another problem that we have to deal with is the "too many instruments problem". Using too many instruments may result in over-fitting biases. When the number of time periods is relatively large, this over-fitting becomes even more serious. The consequent large collection of instruments, even if individually valid, can be collectively invalid because they over-fit endogenous variables (Doornik et al., 2002; Roodman, 2009a, b). They also weaken the Hansen test of overidentifying restrictions used to check instrument validity. Hence, to minimize the over-fitting problem we use the collapse alternative suggested by Roodman (2009b).The empirical results from this panel data analysis are presented and discussed in the next section.

\section{Empirical results}

The findings of this study are reported and carefully discussed in this section. We start by considering several alternative estimators; then we dig deeper on the timing of elections and its frequency; the distinction between developed and developing countries and political systems is taken into account next;and some robustness checks are provided at the end of this section. 


\subsection{Initial estimates}

The results from the estimation of our baseline model are presented in Table 1. We report not only the results from the one-step and two-step differences and system-GMM estimators, but also the FE and LSDVC estimators (all with robust standard-errors). Despite our choice goes to the one-step differences-GMM estimator - for the reasons explained above - we consider a good practice, at this stage, to report the results of the other "competing" estimators. This is relevant not only to show their differences, but also - and more importantly - to emphasize the consistency of our main results.

\section{[Insert Table 1 around here]}

Looking first at the results provided by our preferred estimator (column 1), we observe that during election years the growth rate of human development is significantly higher (around 0.05 percentage points) than in non-election years. ${ }^{13}$ This means that the traditional political (business) cycles observed in GDP growth and public accounts/expenditures are also present in this broader dimension of well-being. This is a striking finding in the way it reveals the existence of an electorally determined cycle, thus highlighting the role of democratic features in shaping the growth path of human development. Nevertheless, the political orientation of the government seems to be innocuous for that path: left-wing governments are not more prone to promote human development than centre or right-wing parties. But majority governments (forming a coalition or not) have a marginal negative impact on the growth rate of human development, perhaps because they can set their own agenda without the need of reaching a broader consensus from other parties, which ends up having a negative effect on general well-being.

As expected, another important result to emphasize is that the economic environment matters for human development: an improvement in the economic risk rating is immediately reflected on the path of human development. However, general financial and political enhancements and population growth have not proved to play a significant role in terms of well-being. Interestingly, the growth rate of human development has shown to decrease over 
time, which indicates lower improvements in the general human development in the more recent years.

These findings are robust to the choice of the kind of GMM estimator (one-step or two-steps; differences or system), but the system-GMM estimator has proved not to fit very well to the data. Contrary to the differences-GMM estimator, ${ }^{14}$ no persistency is found and the Hansen and differences-in-Hansen tests reject the validity of the instruments and the additional moment restrictions. Moreover, the main findings are also robust to the use of standardized variables (see column 5 in Table 1). The economic environment seems to impacts significantly on the HDI path. We might think that the magnitude of political cycle effects could be small, but it is not; when compared to the impact of EcoRating our election dummy reveals roughly $14 \%$ its impact while our majority governments dummy reaches $58 \%$ and both political variables remain quite strong and statistically significant. ${ }^{15}$

The results are even robust to biased/inconsistent dynamic fixed effects estimator (see column 6 in Table 1), which might indicate that the bias can be negligible. In fact, correcting the bias with the LSDVC estimator does not generate significantly different results. ${ }^{16}$ Nevertheless, for the reasons indicated in the previous section, we proceed our analysis employing the one-step robust standard errors differences-GMM estimator.

We also performed some experiments using the alternative estimation approach discussed in section 3 and did a first-stage examination of what impact political variables have on the expenditures related to the non-economic components of the index (health and education) followed by a second-stage, where we explore the effect of these spending adjustments on the HDI. Overall, the results found are consistent with those reported on Table 1, although depicting a slightly weaker relationship between political variables and development, probably related to the significant loss in the number of observations when using this approach (these results are available upon request).

\subsection{Elections timing, political orientation and support, and institutional issues}

In the following set of experiments we test the sensitivity of our results to changes in the political variables, in the controllers and to cross effects between the variables. The results are presented in Table 2. We start by exploring the political cycle in greater depth, focusing on the 
timing of the elections (columns 1-3). In a first approach, we check whether the government's behaviour starts to exert any significant effect on human development before election years. Thus, we add to the equation a dummy variable that takes the value of one in the year before the elections (BefElect_yr). The results show that the electoral cycle over the growth rate of HDI is only present in election years.

\section{[Insert Table 2 around here]}

Next, we replace the BefElect_yr and Elect_yr variables by a dummy that takes de value of one in the year after the elections, and 0 otherwise (AftElect_yr).We found this effect to be statistically non-significant; we reject the presence of a full or complete opportunistic cycle in the data.

Additionally, instead of using dummies to control for the electoral period, we employ a variable that controls for the timing of the elections by measuring the proportion of time that has elapsed since the last election, i.e. it measures the proportion of time a government is in office in a particular year, since it has been elected (TimingElect). ${ }^{17}$ The results are consistent with the idea that policymakers behave opportunistically: as elections approach they manipulate fiscal policy to improve welfare and well-being of their constituents in order to increase their support and maximize their chances of winning the elections. Regarding the other variables, the results remain unchanged.

In the following experiments the other variables are replaced by some proxies. The dummy LeftGov is replaced by RightGov (which takes value one when a right-wing party is in office; 0 otherwise). Majority and coalition dummies are also replaced by the fraction of seats held by the government (Maj\%, which is calculated by dividing the number of government seats by the total number of seats in the parliament). However, no significant coefficients are found for those proxies.

Even though the political risk rating is never statistically relevant, we decided to test some of its components or related variables. Hence, in columns (6), we present the results with those that proved to be significant: the degree of democracy (Democracy, which is an index that represents a polity scale ranging from -10 to +10 , i.e. strongly autocratic to strongly democratic; it is the 'polity2' variable in the Polity IV Database); and a corruption index (Corruption, which 
is published by the ICRG and ranges from 1 to 5 , i.e. low corruption to high corruption). The results are in line with our expectations, since more democracy and less corruption are beneficial for human development. ${ }^{18}$ However, the effects of these institutional components of the political environment have not proved to be consistent. For example, when we add a variable to control for the size of government (GovSize) their statistical significance vanishes. Moreover, the size of government also appears not to influence the growth rate of human development in the group of 55 countries for which the data is available. ${ }^{19}$

In column (8) we report a regression with a composite risk rating (CompRisk) computed using the economic, financial and political risk rating variables. This composite rating is computed by the ICRG. The political risk rating contributes $50 \%$ of the composite rating, while the financial and economic risk ratings each contribute $25 \%$. The results indicate that the better the general economic, financial and political environment is, the more the human development grows. However, we can easily conclude that this effect is mostly due to improvements in the economic conditions.

In general, despite all these experiments, our main findings remain valid: elections and economic environment have a positive impact on the growth rate of human development, while majority governments tend to exert a negative influence. Additionally, we treat the risk rating variables as endogenous in the last regression in Table 2. Nevertheless, our results are not affected. $^{20}$

\subsection{Frequency of elections}

Another important issue to be considered in this analysis is whether the frequency of elections can affect the political cycle in the human development. Are longer cycles responsible for more opportunism than shorter cycles? Can human development benefit from low or high frequency elections? What 'kind of democracy' might be better? To get some clues on how to answer these complex questions we have to find a way of identifying countries with different frequencies of elections. The most practical way is to divide them according to the average 
duration of mandates: one with low durations (high frequency); the other with high durations (low frequency).

The next challenge is to define the threshold between high and low frequencies. A very straightforward solution is to consider the average duration among the panel of countries used in our analysis: 3.8 years. $^{21}$ Thus, we can estimate one model for the group of countries that present a high frequency of elections (average duration of mandates lower that 3.8 years), and other for the group with a lower frequency of elections (duration higher or equal to 3.8 years). The respective results are presented in columns (1) and (2) in Table 3. They are very clear in pointing out that political cycles are a characteristic of countries where governments' mandates are longer. ${ }^{22}$ These provide the necessary time for policymakers to develop and implement the (opportunistic) measures that will promote a significant increase in well-being, precisely when they need to maximize their political support, i.e. in the election years. As longer mandates are mainly a consequence of political stability, our results indicate that more politically stable democracies seem to be more prone to opportunistic manipulation. This is also consistent with the notion that some development measures are not short-term based, thus requiring more time to be implemented.

\section{[Insert Table 3 around here]}

This finding is confirmed when we run a regression with all countries but distinguishing elections in countries where they are more frequent (multiplying Elect_yr with the dummy MoreFreq that takes the value of one in countries with an average duration of mandates lower than 3.8 years: Elect*MoreFreq) from elections in countries where they are less frequent (multiplying Elect_yr with the dummy LessFreq that takes the value of one in countries with an average duration of mandates higher than 3.8 years: Elect*LessFreq). We also test whether the difference in the coefficients is significant (Diff_ElectFreq). Even though the difference is not statistically significant, only countries where governments have longer mandates present a significant political cycle on human development. This same conclusion is obtained if we replace Elect_yr by TimingElect and multiply it by MoreFreq (Timing*MoreFreq) and LessFreq (Timing*LessFreq). 
These results have also proved to be robust to small changes in the threshold. We tried other ad hoc thresholds at 3.5, 3.6, 4, and 4.2 years but the results described above remained qualitatively unchanged. We also report the results using as threshold for the frequency of elections the mean duration of mandates observed in the sub-group of OECD countries (i.e. 3.4 years - see columns 5-8), which are also the most developed countries in our sample. The results are in line with the ones reported above, pointing out to a clear political cycle in the countries with less frequent elections (i.e. frequency higher than 3.4 years). In this case, a significant difference between the two groups of countries is found when the variable TimingElect multiplied by the dummies for the frequency of elections is employed. ${ }^{23}$

\subsection{Advanced vs developing economies and political systems}

The literature on political business cycles has demonstrated that the opportunistic behaviour tends to gather more support in developing countries than in advanced economies (Shi and Svensson, 2006; Brender and Drazen, 2005, 2008; Vergne, 2009). To account for this issue in the human development, we separate the analysis in two sub-groups of countries: OECD countries (representing the advanced economies); and non-OECD countries (encompassing all the other less developed or developing economies). Moreover, we also distinguish high-income countries (HIC) from countries with lower income (LIC) and between countries with a high-HDI (HHDIC) and low-HDI (LHDIC). ${ }^{24}$ The results are presented in Table 4.

\section{[Insert Table 4 around here]}

The results for the group of OECD countries are shown first, followed by the ones for non-OECD or less developed economies (see columns 1 and 2). Despite economic conditions being important in both sub-sets, we corroborate the idea that governments' opportunistic behaviour is a characteristic of less developed countries. In particular, human development rises more significantly during election periods in those economies than in more advanced ones. The effect in the OECD countries is almost negligible. When dummy variables are used to identify the two sets of countries and multiplied by Elect_yr (Elect ${ }^{*} O E C D$ and Elect $\left.{ }^{*} N o n O E C D\right)-$ in a similar way to what we have done in Table 3 for the frequency of elections - we confirm the 
prominence of political cycles in the human development for non-OECD economies and that the difference to the group of OECD countries is statistically significant (see coefficient on Diff_OECD).

The results reported in columns (4) to (9) are in line with the previous ones, in the sense that they show that countries with lower income and HDI are the ones in which the timing of the elections matter for the evolution of human development, with a significant difference relatively to the other groups (HIC or HHDIC). ${ }^{25}$

The type of political regime/system may also play a role on how human development behaves. ${ }^{26}$ Issues like whether the system is presidential or not, whether there is plurality or not, and whether there is proportional representation or not deserve to be considered as different political systems can generate different outcomes. As these characteristics of the electoral design do not exhibit time variability we cannot explicitly include them in the model to control for their impact, because they are dropped in the GMM estimations. Thus, the alternative is to estimate separate regressions for each kind of political system/regime. Additionally, we can also evaluate the significance of the differences in the political cycle behaviour (Diff_\#) by looking at the impact of the product between Elect_yr and a dummy for the respective regime (Elect*Presid and Elect*NonPresid; Elect*Plural and Elect*NonPlural; Elect*PR and Elect*NonPR), in a similar way to what we have done above. ${ }^{27}$ The results for the respective estimations are presented in Table 5.

\section{[Insert Table 5 around here]}

Presidential and non-plurality regimes and proportional representation systems are the ones in which human development exhibits an electoral cycle. These results are in line with the works of Persson and Tabellini (2002) and Gassner et. al. (2006). However, the difference for their counterpart systems/regimes has not proved to be very relevant (see coefficients on Diff_\#, for each case) and partisan effects remain absent from all estimations. We also verify that despite economic conditions matter independently of the kind of political system/regime, majority governments tend to be more "active" in non-plurality systems and in proportional representation regimes. 


\subsection{Robustness checks}

As the data for HDI and its three components (Life Expectancy, Education and Income indices) are only available for periods of five years between 1980 and 2000, the missing data were obtained by linear interpolation for each of its three components. The HDI was then computed as the cubic root of the product of those three components for the entire time period (1980-2013). To check for the robustness of our results, we did some additional regressions where different kinds of interpolations to obtain the missing values for HDI are used, as well as different time periods. To circumvent any remaining issues with interpolation, we also estimated the mode for shorter and more recent time periods (where fewer years are interpolated or where there is no interpolation at all): 1990-2013, 2000-2013, and 2005-2013. Independently of the kind of interpolation or time period considered, the results and conclusions of this study remain unchanged. However, we found that the magnitude of the coefficient on Elect_yr increases as we restrict the time period to more recent years, which points out to an intensification of political cycle over time and that this effect is concentrated in the group of non-OECD (or less developed) countries.

As the HDI variable is computed based on three important indices (Income, Education and Health indices), we also tried to understand which index contributes more for the political cycle identified in the growth rate of HDI (HDI_gr). That separate analysis indicates that besides income - that plays an important role - education standards also play a part, although a minor one, in explaining the presence of political cycles in the HDI. Hence, the evidences of political cycles found in this paper are not exclusively focused on income, but also show some social features. All results mentioned are available upon request.

\section{Conclusions}

This study represents a first attempt of analysing the role of democratic features in the shaping of human development's growth path. The traditional analysis of political cycles has focused essentially on the business or economic cycle, and assumes that governments are only interested in providing economic well-being, thus neglecting other relevant dimensions that 
economic agents tend to value like better education and health services, broader participation in economic, cultural and political activities of the local community, improvements in working conditions and security against crime and physical violence. Since the HDI, developed by the United Nations (UNDP), covers multi-dimension aspects of economic development, we use it to analyse the electoral dynamics of human development.

Using data for 82 countries over the period 1980-2013 and employing a GMM estimator we were able to identify the presence of a political development cycle. During election years the growth rate of human development is significantly higher than in non-election years and probably the primary source of this may reside in public spending variations especially for social dimensions. It seems that governments near elections deliver more than strict economic well-being, and thus the standard economic cycle found in the literature is only a part of the actual socio-economic cycle generated by elections. We also found that the electoral cycle over the growth rate of HDI is only present in election years, nothing was found before or after, and that this cycle has become stronger in the recent years. This might mean that, as countries prosperity increases over time, politicians are more aware of voters' social preferences and the increasing value they put on non-economic well-being.

Our results provide no evidence of left-wing governments being more prone to promote human development than other types of rulers. The political orientation of governments was consistently found to be innocuous for the growth path of human development. On the contrary, majority governments seem be associated with a decrease in the growth rate of human development.

A further detailed analysis accounting for some important characteristics of democracies showed that human development rises more significantly during election periods in less developed countries than in more advanced ones (the effect found for OECD countries is almost negligible). Moreover, the opportunistic development cycle seems to be a characteristic of countries where government mandates are longer and of proportional representation systems. 
${ }^{1}$ Bloom and Friedman (1997), Bloom and Williamson (1998) and Bloom et al. (2003) also show that the drop in the economic dependency ratio has an impact on how human development evolves over time.

${ }^{2}$ Rational versions of opportunistic models tend to reduce the ability of policymaker's to induce the political cycle. Empirical studies suggest that favourable economic conditions do benefit governments (Hibbs, 2006).However, opportunistic behaviour appears to gather more support in developing countries (see, for instance, Shi and Svensson, 2002a,b, 2006; Brender and Drazen, 2008; and Vergne, 2009).

${ }^{3}$ Veiga and Veiga (2007), Drazen and Eslava (2010), Aidt et al. (2011) and Sakurai and Menezes-Filho (2011) also found political opportunism at aggregated and disaggregated levels of public expenditures but restricted to the municipal level of government.

${ }^{4}$ In general, empirical evidence points out that partisan behaviour seems to be more recurrent in developed countries (see Alesina et al., 1992, 1997).

${ }^{5}$ Studies that take a look at disaggregated public expenditures found none or weak support for partisan effects in welfare related areas. See, for instance Enkelman and Leibrecht (2013) and Castro and Martins (2016).

${ }^{6}$ The countries used in this study are listed in Table A.1 in Annex.

${ }^{7}$ For details on how the HDI is computed, see the Technical Notes of the Human Development Report at http://hdr.undp.org/en/data. As the data for HDI and its three components (Life Expectancy, Education and Income indices) are only available for periods of five years between 1980 and 2000, the missing data were obtained by linear interpolation for each of the three components (more recent data are provided annually); then the HDI was computed as the cubic root of the product of those three components for the entire time period (1980-2013). A direct linear interpolation of HDI was also considered, as well as cubic and natural cubic spline interpolations, in some robustness checks. To circumvent any remaining issues with interpolation, we also report estimations for shorter and more recent time periods, where fewer years are interpolated or where there is no interpolation at all: 1990-2013; 2000-2013; 2005-2013. However, independently of the kind of interpolation and time period used, the results and conclusions of this study remain unchanged.

${ }^{8} \mathrm{An}$ increase in the economic, financial or political rating risk index means an improvement in the respective rating risk, i.e., that the economic, financial or political environment has improved.

${ }^{9}$ We prefer to control for the impact of the economy using this indicator instead of GDP or income per capita or other related variable. As one of the components of the HDI is precisely an income index, using those variables as regressors would certainly be highly correlated with HDI.

${ }^{10}$ The 12 components are: government stability, socioeconomic conditions, investment profile, internal conflict, external conflict, corruption, military in politics, religious tensions, law and order, ethnic tensions, democratic accountability, and bureaucracy quality. For details, see ICRG at http://www.prsgroup.com.

${ }^{11}$ Judson and Owen (1999) notice that even for $T=30$ the bias can be as much as $20 \%$ of the true value of the coefficient of interest.

${ }^{12}$ For this difference in GMM estimator to be consistent, it must be ensured that there is no autocorrelation in the errors and no correlation between individuals in the residuals. The passage of time is considered in the specification to overcome this problem.

${ }^{13}$ Even though the magnitude of this effect seems small, we should note that, on average, the HDI grows very slowly over time. Hence, we cannot expect higher magnitudes for the estimated coefficients.

${ }^{14}$ The differences-GMM estimator requirements are fulfilled as the Hansen tests does not reject the validity of the instruments and there is autocorrelation in the first order but not of second order.

${ }^{15}$ We follow Gelman (2008) to standardize our variables. The author proposes dividing each numeric variable by two times its standard deviation, so that the generic comparison is with inputs equal to the mean \pm 1 standard deviation. The resulting coefficients are then directly comparable for untransformed binary predictors.

${ }^{16}$ In the LSDVC regressions, we employ the Arellano and Bond (1991) estimator as the initial estimator, collapsing the instruments as suggested by Roodman (2009a, b). Following Bloom et al. (2007), we undertake 50 repetitions of the procedure to bootstrap the estimated standard errors. Nevertheless, results do not qualitatively change with different repetitions $(25,100$ or even 200$)$. 
${ }^{17}$ It is equal to 1 in the election year.

18 Aidt (2011) provides evidence of a negative impact of corruption on sustainable development.

${ }^{19}$ GovSize is the ' $f$ i_sog' index in the Economic Freedom of the World published by the Fraser Institute. Despite those effects are not relevant in our sample, Martins and Veiga (2014) have found a significant impact of government size on human development in a larger panel of 156 countries and using a convergence specification with 5-year time spans. Our sample only includes countries with established democracies.

${ }^{20} \mathrm{We}$ also tried to test for government turnover effects using a dummy that accounts only for those elections in which there are changes in the ideology of the government, but, in this case, no significant impact was found on human development. Additionally, we tested for the presence of interaction effects between Elect_yr and GovLeft, GovMaj and EcoRating, but the respective coefficients were also always statistically insignificant. These results are not reported here to save space, but they are available upon request.

${ }^{21}$ Another option could be to consider differences in the constitutional duration of terms in each country. However, we would face the problem that, in general, they are not very different (usually set at four years).

${ }^{22}$ For the countries in each sample see Table A.1 in Annex. As the number of countries is low when we split the sample, an LSDVC was also used. The results - not reported here to save space - have proved to be very similar.

23 The results for the additional covariates are not reported to save space, but they are available upon request.

${ }^{24}$ High-income countries are those are those that, according to the World Bank in 2014, have a GNI per capita of $\$ 12,736$ or more. For the high-HDI group are considered those that, according to the United Nations Development Program, have an HDI higher than 0.800 .

${ }^{25}$ The HIC, LIC, HHDIC and LHDIC variables in the specifications (multiplied by Elect_yr) are dummies that take the value of one if a country belongs to that group (the differences between the respective coefficients are given by Diff_IC and Diff_HDI). An LSDVC estimator was also used for each sub-sample, but the results did not change. They are not shown here to save space, but they are available upon request.

${ }^{26}$ Persson and Tabellini (2002) and Gassner et. al. (2006) show that electoral cycles differ across political systems.

27 Presid takes de value of one in presidential systems, i.e. when the head of government is also head of state and leads an executive branch separated from the legislative branch, and 0 otherwise (NonPresid). Plural takes the value of one in plurality systems, i.e. when legislators are elected using a 'winner-take-all' rule, and 0 otherwise (NonPlural). PR takes the value of one in proportional representation regimes, i.e. in those regimes in which candidates are elected based on the percent of votes received by their party, and 0 otherwise (NonPR). 


\section{References}

Aidt, T., 2011. Corruption and sustainable development. In: Rose-Ackerman, S., Soreide, T. (Eds.). International Handbook on the Economics of Corruption, Vol. II, Ch. 1. Cheltenham, UK: Edward Elgar Publishing.

Aidt, T., Veiga, F., Veiga, L., 2011. Election Results and Opportunistic Policies: A New Test of the Rational Political Business Cycle Model. Public Choice, 148, 21-44.

Alesina, A., 1987. Macroeconomic Policy in a Two-Party System as a Repeated Game. Quarterly Journal of Economics, 1023, 651-78.

Alesina, A., Sachs, J., 1988. Political Parties and Business Cycle in the United States, 1948-84. Journal of Money, Credit, and Banking, 201, 63-82.

Alesina A., 1988. Macroeconomics and politics. Nat. Bur. Econ. Res. Macroeconomics Annual. 3:13-61.

Alesina A, Cohen, G, Roubini, N., 1992. Macroeconomic policies and elections in OECD democracies. Economics \& Politics., 41, 1-30

Alesina, A., Cohen, G., Roubini, N., 1997. Political Cycles and the Macroeconomy. Cambridge, Mass. and London, The MIT Press.

Alkire, S., 2007. The missing dimensions of poverty data: Introduction to the special issue. Oxford Development Studies, 35(4), 347-359.

Arellano, M., Bond, S., 1991. Some Tests of Specification for Panel Data: Monte Carlo Evidence and an Application to Employment Equations. Review of Economic Studies, 58, 277-297.

Arellano, M., Bover, S., 1995. Another look at the instrumental variable estimation of error components models. Journal of Econometrics, 68, 29-51.

Baltagi, B., 2008. Econometric Analysis of Panel Data, 4th Ed. Chichester, UK. John Wiley \& Sons, Ltd.

Blais, A., Nadeau, R., 1992. The Electoral Budget Cycle. Public Choice, 744, 389-403.

Bloom, D., Freeman, R., 1987. Population growth, labor supply, and employment in developing countries. National Bureau of Economic Research, NBER Working Paper No. 1837.

Bloom, D., Williamson, J., 1998. Demographic transitions and economic miracles in emerging Asia. World Bank Economic Review, 12(3), 419-455. 
Bloom, D., Canning, D., Sevilla, J., 2003. The demographic dividend: A new perspective on the economic consequences of population change. RAND Monograph Report.

Bloom, D., Canning, D., Mansfield, R., Moore, M., 2007. Demographic change, social security systems, and savings. Journal of Monetary Economics, 54(1), 92-114.

Blundell R., Bond, S., 1998. Initial conditions and moment restrictions in dynamic panel data models. Journal of Econometrics, 87(1), 115-143.

Brender, A., Drazen, A., 2005. Political budget cycles in new versus established democracies. Journal of Monetary Economics, 52(7), 1271-1295.

Brender, A., Drazen, A., 2008. How do budget deficits and economic growth affect Reelection prospects? Evidence from a large panel of countries. American Economic Review. 98, 2203-2220.

Bruno, G., 2005a. Estimation and inference in dynamic unbalanced panel-data models with a small number of individuals. Stata Journal, 5(4), 473-500.

Bruno, G., 2005b. Approximating the bias of the LSDV estimator for dynamic unbalanced panel data models. Economics Letters, 87(3), 361-366.

Castro, V., Martins, R., 2016. Political cycles and government expenditures: evidence from Portugal. Applied Economics Letters, 23(1), 34-37.

Comim, F., Qizilbash, M., Alkire, S., 2008. The capability approach: Concepts, measures and applications. Cambridge: Cambridge University Press.

Dasgupta, P., 2001. Human well-being and the natural environment. Oxford: Oxford University Press.

Davies, A., 2009. Human development and the optimal size of government. Journal of Socio-Economics, 38, 326-330.

Doornik, J., Arellano, M., Bond, S., 2002. Panel Data Estimation Using DPD for OX: Manuscript. Oxford University.

Drazen, A., Eslava, M., 2010. Electoral manipulation via voter-friendly spending: Theory and Evidence. Journal of Development Economics 92 (1), 39-52.

Fleurbaey, M., 2009. Beyond GDP: The quest for a measure of social welfare. Journal of Economic Literature, 474, 1029-1075.

Frey, B., Stutzer, A., 2002. Happiness and Economics: How the economy and institutions affect human well-being. Princeton, NJ: Princeton University Press. 
Franzese, R., 2002. Electoral and Partisan cycles in economic policies and outcomes. Annual Review of Political Science, 5, 369-421.

Fukuda-Parr, S., Shiva-Kumar, A., 2003. Readings in human development: Concepts, measures and policies for a development paradigm. Oxford: Oxford University Press.

Gassner, M., Ontivernos, D., Verardi, V., 2006. Human development and Electoral Systems. Journal of Human development, 7(1), 43-57.

Andrew Gelman, A. (2008). Scaling regression inputs by dividing by two standard deviations. Statistics in Medicine, 27, 2865-2873.Hibbs, D.A. Jr. (1977). Political Parties and Macroeconomic Policy. American Political Science Review, 71, 1467-87.

Imbeau, L., Pétry, F., Lamari, M., 2001. Left-right party ideology and government policies: a meta-analysis. European Journal of Political Research, 40, 1-29.

Judson, R., Owen, L., 1999. Estimating Dynamic Panel Data Models: A Guide for Macroeconomists. Economics Letters, 65, 9-15.

Martins, S., Veiga, F., 2014. Government size, composition of public expenditure, and economic development. International Tax and Public Finance, 21, 578-597.

Miller, M., 2015. Electoral Authoritarianism and Human development. Comparative Political Studies, 48(12), 1526-62.

Molina, G., Purser, M., 2010. Human development trends since 1970: A social convergence story. Human Development Research Paper, 2010/2.

Moshirian, F., Wu, Q., 2012. Banking industry volatility and economic growth. Research in International Business and Finance, 26, 428-442.

Nafziger, E., 2012. Economic development, $5^{\text {th }}$ Ed., New York: Cambridge University Press.

Nordhaus, W. (1975). The Political Business Cycle. Review of Economic Studies, XLII, 169-90.

Persson, T., Tabellini, G., 2002. Do electoral cycles differ across political systems? Working Paper No. 232. IGIER, Bocconi University.

Potrafke, N., 2010. The growth of public health expenditures: do government ideology and electoral motives matter? Journal of Health Economics, 296, 797-810.

Ranis, G., Stewart, F., Samman, E., 2005. Human development: Beyond the HDI. Yale University, Economic Growth Center Paper No. 916.

Rogoff, K., 1990. Equilibrium Political Budget Cycles. American Economic Review. 801, 21-36.

Rogoff, K., Sibert, A., 1988. Elections and Macroeconomic Policy Cycles. Review of Economic Studies. LV1, 1-16. 
Roodman, D., 2009a. How to do xtabond2: An introduction to difference and system GMM in Stata. Stata Journal, 9(1), 86-136.

Roodman, D. M. 2009b. A note on the theme of too many instruments. Oxford Bulletin of Economics and Statistics 71: 135-158.

Sakurai, S., Menezes-Filho, N., 2011. Opportunistic and partisan election cycles in Brazil: new evidence at the municipality level. Public Choice, 148, 233-247.

Sen, A., 1999. Development as freedom. New York: Random House.

Shi, M., Svensson, J., 2002a. Conditional political budget cycles. CEPR Discussion Paper \#3352.

Shi, M., Svensson, J., 2002b. Political business cycles in developed and developing countries, working paper, IIES, Stockholm University.

Shi, M., Svensson, J., 2006. Political budget cycles: Do they differ across countries and why? Journal of Public Economics, 90, 1367-1389.

Timmer, P., Akkus, S., 2008. The structural transformation as a way out of poverty: Analytics, empirics and politics. Center for Global Development Working Paper 150.

Ul Haq, M., 1995. The birth of the human development index. In: Fukuda-Parr, S., Shiva-Kumar, A. (Eds.). Readings in human development: Concepts, measures and policies for a development paradigm. Oxford: Oxford University Press.

United Nations Development Program (UNDP), 2014. Human Development Report. New York, NY: United Nations.

Veiga, F. and L. Veiga (2007). Political business cycles at municipal level. Public Choice, 131(1-2), 45-64.

Vergne, C., 2009. Democracy, elections and the allocation of public expenditures in developing countries. European Journal of Political Economy 25, 63-77.

Wilensky, H., 1976. The "New Corporatism", Centralization and the Welfare State. Beverly Hill, CA: Sage.

Wolfers, J., 2009. What does the human development index measure? Freakonomics Blog, http://freakonomics.blogs.nytimes.com/2009/05/22/what-does-the-humandevelopment -index-measure/. 
Tables

Table 1. Political cycles in the growth rate of human development

\begin{tabular}{|c|c|c|c|c|c|c|c|}
\hline & DifGMM1 & DifGMM2 & SysGMM1 & SysGMM2 & DiffGMM1S & Dyn-FE & LSDVC \\
\hline & (4) & $(5)$ & (6) & (7) & $(1)$ & (2) & (3) \\
\hline$L . H D I \_g r$ & $\begin{array}{c}0.376^{* * * *} \\
(0.097)\end{array}$ & $\begin{array}{c}0.329 * * * \\
(0.108)\end{array}$ & $\begin{array}{c}0.189 \\
(0.150)\end{array}$ & $\begin{array}{c}0.156 \\
(0.146)\end{array}$ & $\begin{array}{c}0.277 * * * \\
(0.108)\end{array}$ & $\begin{array}{c}0.352 * * \\
(0.156)\end{array}$ & $\begin{array}{c}0.403 * * * \\
(0.024)\end{array}$ \\
\hline Elect_yr & $\begin{array}{c}0.054 * * \\
(0.025)\end{array}$ & $\begin{array}{c}0.037 * * \\
(0.019)\end{array}$ & $\begin{array}{c}0.051 * * \\
(0.021)\end{array}$ & $\begin{array}{c}0.035^{* *} \\
(0.017)\end{array}$ & $\begin{array}{c}0.035 * * \\
(0.017)\end{array}$ & $\begin{array}{c}0.053 * * \\
(0.023)\end{array}$ & $\begin{array}{c}0.054 * * \\
(0.027)\end{array}$ \\
\hline GovLeft & $\begin{array}{c}0.003 \\
(0.038)\end{array}$ & $\begin{array}{l}-0.001 \\
(0.039)\end{array}$ & $\begin{array}{l}-0.007 \\
(0.032)\end{array}$ & $\begin{array}{c}-0.002 \\
(0.037)\end{array}$ & $\begin{array}{l}-0.038 \\
(0.035)\end{array}$ & $\begin{array}{l}-0.032 \\
(0.020)\end{array}$ & $\begin{array}{l}-0.030 \\
(0.030)\end{array}$ \\
\hline GovMaj & $\begin{array}{l}-0.152^{*} \\
(0.083)\end{array}$ & $\begin{array}{l}-0.116 \\
(0.076)\end{array}$ & $\begin{array}{l}-0.136 \\
(0.086)\end{array}$ & $\begin{array}{l}-0.088 \\
(0.081)\end{array}$ & $\begin{array}{l}-0.151^{*} \\
(0.089)\end{array}$ & $\begin{array}{c}-0.155^{* *} \\
(0.061)\end{array}$ & $\begin{array}{c}-0.145^{* * * *} \\
(0.045)\end{array}$ \\
\hline GovCoal & $\begin{array}{l}-0.079 \\
(0.084)\end{array}$ & $\begin{array}{l}-0.064 \\
(0.083)\end{array}$ & $\begin{array}{l}-0.080 \\
(0.077)\end{array}$ & $\begin{array}{l}-0.050 \\
(0.081)\end{array}$ & $\begin{array}{l}-0.049 \\
(0.087)\end{array}$ & $\begin{array}{l}-0.066 \\
(0.047)\end{array}$ & $\begin{array}{l}-0.062 \\
(0.038)\end{array}$ \\
\hline MajCoal & $\begin{array}{c}0.091 \\
(0.085)\end{array}$ & $\begin{array}{c}0.055 \\
(0.086)\end{array}$ & $\begin{array}{c}0.094 \\
(0.083)\end{array}$ & $\begin{array}{c}0.046 \\
(0.083)\end{array}$ & $\begin{array}{c}0.076 \\
(0.083)\end{array}$ & $\begin{array}{c}0.123^{* *} \\
(0.062)\end{array}$ & $\begin{array}{c}0.114^{* *} \\
(0.055)\end{array}$ \\
\hline EcoRating & $\begin{array}{c}0.030 * * * \\
(0.009)\end{array}$ & $\begin{array}{c}0.025^{* * * *} \\
(0.008)\end{array}$ & $\begin{array}{c}0.031 * * * \\
(0.009)\end{array}$ & $\begin{array}{c}0.026 * * * \\
(0.009)\end{array}$ & $\begin{array}{c}0.260 * * * \\
(0.075)\end{array}$ & $\begin{array}{c}0.016 * * * \\
(0.005)\end{array}$ & $\begin{array}{c}0.015^{* * *} \\
(0.003)\end{array}$ \\
\hline FinRating & $\begin{array}{c}0.001 \\
(0.004)\end{array}$ & $\begin{array}{c}0.002 \\
(0.004)\end{array}$ & $\begin{array}{c}0.001 \\
(0.004)\end{array}$ & $\begin{array}{c}0.002 \\
(0.004)\end{array}$ & $\begin{array}{c}0.001 \\
(0.051)\end{array}$ & $\begin{array}{c}0.003 \\
(0.003)\end{array}$ & $\begin{array}{c}0.003 \\
(0.003)\end{array}$ \\
\hline PolRating & $\begin{array}{l}-0.003 \\
(0.005)\end{array}$ & $\begin{array}{l}-0.001 \\
(0.004)\end{array}$ & $\begin{array}{l}-0.003 \\
(0.005)\end{array}$ & $\begin{array}{c}0.001 \\
(0.004)\end{array}$ & $\begin{array}{l}-0.026 \\
(0.087)\end{array}$ & $\begin{array}{c}0.001 \\
(0.003)\end{array}$ & $\begin{array}{c}0.001 \\
(0.002)\end{array}$ \\
\hline Pop_gr & $\begin{array}{l}-0.044 \\
(0.035)\end{array}$ & $\begin{array}{l}-0.042 \\
(0.052)\end{array}$ & $\begin{array}{l}-0.044 \\
(0.035)\end{array}$ & $\begin{array}{l}-0.040 \\
(0.052)\end{array}$ & $\begin{array}{l}-0.032 \\
(0.057)\end{array}$ & $\begin{array}{c}-0.022 * * \\
(0.011)\end{array}$ & $\begin{array}{l}-0.019 \\
(0.016)\end{array}$ \\
\hline Time & $\begin{array}{c}-0.012 * * * \\
(0.004)\end{array}$ & $\begin{array}{c}-0.013 * * * \\
(0.004)\end{array}$ & $\begin{array}{c}-0.013 * * * \\
(0.004)\end{array}$ & $\begin{array}{c}-0.014 * * * \\
(0.004)\end{array}$ & $\begin{array}{c}-0.017 * * * \\
(0.003)\end{array}$ & $\begin{array}{c}-0.011^{* * * *} \\
(0.002)\end{array}$ & $\begin{array}{c}-0.010 * * * \\
(0.001)\end{array}$ \\
\hline $\mathrm{R}^{2}$ & & & & & & 0.194 & \\
\hline \# Observations & 1616 & 1616 & 1717 & 1717 & 1616 & 1717 & 1717 \\
\hline \# Countries & 82 & 82 & 82 & 82 & 82 & 82 & 82 \\
\hline \# Instruments & 40 & 40 & 42 & 42 & 40 & & \\
\hline Hansen $J$-test & 0.147 & 0.147 & 0.032 & 0.032 & 0.146 & & \\
\hline Diff. Hansen test & & & 0.081 & 0.081 & & & \\
\hline $\mathrm{AR}(1)$ & 0.007 & 0.017 & 0.000 & 0.042 & 0.000 & & \\
\hline $\mathrm{AR}(2)$ & 0.802 & 0.876 & 0.824 & 0.770 & 0.857 & & \\
\hline
\end{tabular}

Notes: See Tables A.1 and A.2 in Annex. Robust standard errors are in parentheses; significance levels at which the null hypothesis is rejected: ***, 1\%; **, 5\%, and *, 10\%. One-step and two-steps differences and system GMM estimates are reported in columns (1)-(4); column (5) reports the results with standardized variables and column (6) the results for a dynamic fixed effects estimator. Bruno's (2005a, b) LSDVC estimates are shown in the last column. The lagged dependent regressor is treated as endogenous in the GMM estimations; their lagged values and the other explanatory variables are used as instruments in the first-difference equation; the lagged first-differences of the lagged dependent variable were also used in the levels equation in the system GMM estimations; they were collapsed to avoid the problem of having too many instruments. The Hansen $J$-test reports the $p$-value for the null hypothesis of instrument validity. The values reported for the Diff-in-Hansen test are the $p$-values for the validity of the additional moment restriction necessary for the system GMM. The values reported for $\mathrm{AR}(1)$ and $\mathrm{AR}(2)$ are the $p$-values for first and second order auto-correlated disturbances in the first differences equations. 
Table 2. Elections timing, political orientation and support, and institutional issues

\begin{tabular}{|c|c|c|c|c|c|c|c|c|c|}
\hline & (1) & $(2)$ & (3) & (4) & (5) & (6) & $(7)$ & $(8)$ & (9) \\
\hline L.HDI_gr & $\begin{array}{c}0.313 * * * \\
(0.106)\end{array}$ & $\begin{array}{c}0.383 * * * \\
(0.092)\end{array}$ & $\begin{array}{c}0.427 * * * \\
(0.097)\end{array}$ & $\begin{array}{c}0.366^{* * * *} \\
(0.101)\end{array}$ & $\begin{array}{c}0.371 * * * \\
(0.095)\end{array}$ & $\begin{array}{c}0.420 * * * \\
(0.098)\end{array}$ & $\begin{array}{c}0.382 * * * \\
(0.092)\end{array}$ & $\begin{array}{c}0.393 * * * \\
(0.097)\end{array}$ & $\begin{array}{c}0.303 * * \\
(0.121)\end{array}$ \\
\hline Elect_yr & $\begin{array}{c}0.053 * * * \\
(0.016)\end{array}$ & & & $\begin{array}{c}0.039 * * \\
(0.020)\end{array}$ & $\begin{array}{c}0.054 * * \\
(0.024)\end{array}$ & $\begin{array}{c}0.042 * * \\
(0.021)\end{array}$ & $\begin{array}{c}0.041 * * \\
(0.021)\end{array}$ & $\begin{array}{c}0.048 * * \\
(0.024)\end{array}$ & $\begin{array}{c}0.051 * * \\
(0.023)\end{array}$ \\
\hline BefElect_yr & $\begin{array}{l}-0.010 \\
(0.032)\end{array}$ & & & & & & & & \\
\hline AftElect_yr & & $\begin{array}{c}-0.018 \\
(0.016)\end{array}$ & & & & & & & \\
\hline TimingElect & & & $\begin{array}{c}0.060 * * \\
(0.025)\end{array}$ & & & & & & \\
\hline GovLeft & $\begin{array}{c}-0.010 \\
(0.037)\end{array}$ & $\begin{array}{c}-0.013 \\
(0.038)\end{array}$ & $\begin{array}{c}0.018 \\
(0.029)\end{array}$ & & $\begin{array}{c}0.013 \\
(0.036)\end{array}$ & $\begin{array}{c}0.006 \\
(0.032)\end{array}$ & $\begin{array}{c}-0.004 \\
(0.033)\end{array}$ & $\begin{array}{c}-0.008 \\
(0.037)\end{array}$ & $\begin{array}{l}-0.026 \\
(0.037)\end{array}$ \\
\hline GovRight & & & & $\begin{array}{c}0.020 \\
(0.035)\end{array}$ & & & & & \\
\hline GovMaj & $\begin{array}{c}-0.177 * * \\
(0.082)\end{array}$ & $\begin{array}{c}-0.151 * \\
(0.082)\end{array}$ & $\begin{array}{c}-0.130^{*} \\
(0.078)\end{array}$ & $\begin{array}{c}-0.157^{*} \\
(0.087)\end{array}$ & & $\begin{array}{c}-0.215^{* *} \\
(0.101)\end{array}$ & $\begin{array}{c}-0.247 * * \\
(0.104)\end{array}$ & $\begin{array}{c}-0.147 * \\
(0.087)\end{array}$ & $\begin{array}{c}-0.170 * * \\
(0.077)\end{array}$ \\
\hline GovCoal & $\begin{array}{l}-0.079 \\
(0.081)\end{array}$ & $\begin{array}{l}-0.072 \\
(0.085)\end{array}$ & $\begin{array}{c}0.019 \\
(0.056)\end{array}$ & $\begin{array}{l}-0.097 \\
(0.092)\end{array}$ & & $\begin{array}{l}-0.052 \\
(0.094)\end{array}$ & $\begin{array}{c}-0.077 \\
(0.094)\end{array}$ & $\begin{array}{l}-0.095 \\
(0.087)\end{array}$ & $\begin{array}{c}-0.050 \\
(0.079)\end{array}$ \\
\hline MajCoal & $\begin{array}{c}0.112 \\
(0.081)\end{array}$ & $\begin{array}{c}0.083 \\
(0.084)\end{array}$ & $\begin{array}{c}0.050 \\
(0.077)\end{array}$ & $\begin{array}{c}0.107 \\
(0.087)\end{array}$ & & $\begin{array}{c}0.119 \\
(0.097)\end{array}$ & $\begin{array}{c}0.153 \\
(0.095)\end{array}$ & $\begin{array}{c}0.090 \\
(0.090)\end{array}$ & $\begin{array}{c}0.122 \\
(0.084)\end{array}$ \\
\hline Maj\% & & & & & $\begin{array}{c}-0.099 \\
(0.157)\end{array}$ & & & & \\
\hline EcoRating & $\begin{array}{c}0.030 * * * \\
(0.009)\end{array}$ & $\begin{array}{c}0.030 * * * \\
(0.009)\end{array}$ & $\begin{array}{c}0.027 * * * \\
(0.009)\end{array}$ & $\begin{array}{c}0.022 * * * \\
(0.005)\end{array}$ & $\begin{array}{c}0.030 * * * \\
(0.009)\end{array}$ & $\begin{array}{c}0.026 * * * \\
(0.006)\end{array}$ & $\begin{array}{c}0.024 * * * \\
(0.006)\end{array}$ & & $\begin{array}{c}0.025 * * * \\
(0.005)\end{array}$ \\
\hline FinRating & $\begin{array}{c}0.001 \\
(0.004)\end{array}$ & $\begin{array}{c}0.001 \\
(0.004)\end{array}$ & $\begin{array}{c}0.001 \\
(0.004)\end{array}$ & $\begin{array}{c}0.003 \\
(0.004)\end{array}$ & $\begin{array}{c}0.001 \\
(0.004)\end{array}$ & $\begin{array}{c}-0.001 \\
(0.004)\end{array}$ & $\begin{array}{c}-0.001 \\
(0.004)\end{array}$ & & $\begin{array}{c}0.004 \\
(0.004)\end{array}$ \\
\hline PolRating & $\begin{array}{l}-0.005 \\
(0.005)\end{array}$ & $\begin{array}{l}-0.002 \\
(0.005)\end{array}$ & $\begin{array}{l}-0.007 \\
(0.006)\end{array}$ & $\begin{array}{c}0.001 \\
(0.003)\end{array}$ & $\begin{array}{l}-0.003 \\
(0.005)\end{array}$ & & & & $\begin{array}{c}0.002 \\
(0.004)\end{array}$ \\
\hline Democracy & & & & & & $\begin{array}{l}0.051 * \\
(0.027)\end{array}$ & $\begin{array}{c}0.041 \\
(0.026)\end{array}$ & & \\
\hline Corruption & & & & & & $\begin{array}{c}-0.047 * \\
(0.028)\end{array}$ & $\begin{array}{l}-0.039 \\
(0.027)\end{array}$ & & \\
\hline GovSize & & & & & & & $\begin{array}{c}0.024 \\
(0.037)\end{array}$ & & \\
\hline CompRating & & & & & & & & $\begin{array}{c}0.017 * * * \\
(0.004)\end{array}$ & \\
\hline Pop_gr & $\begin{array}{l}-0.033 \\
(0.034)\end{array}$ & $\begin{array}{l}-0.049 \\
(0.037)\end{array}$ & $\begin{array}{l}-0.049 \\
(0.039)\end{array}$ & $\begin{array}{l}-0.026 \\
(0.028)\end{array}$ & $\begin{array}{l}-0.049 \\
(0.034)\end{array}$ & $\begin{array}{l}-0.052 \\
(0.079)\end{array}$ & $\begin{array}{c}-0.071 \\
(0.084)\end{array}$ & $\begin{array}{l}-0.047 \\
(0.035)\end{array}$ & $\begin{array}{l}-0.058 \\
(0.038)\end{array}$ \\
\hline Time & $\begin{array}{c}-0.011 * * * \\
(0.003)\end{array}$ & $\begin{array}{c}-0.014 * * * \\
(0.004)\end{array}$ & $\begin{array}{c}-0.007 * * \\
(0.004)\end{array}$ & $\begin{array}{c}-0.014 * * * \\
(0.004)\end{array}$ & $\begin{array}{c}-0.012 * * * \\
(0.004)\end{array}$ & $\begin{array}{c}-0.019 * * * \\
(0.004)\end{array}$ & $\begin{array}{c}-0.018 * * * \\
(0.005)\end{array}$ & $\begin{array}{c}-0.013 * * * \\
(0.004)\end{array}$ & $\begin{array}{c}-0.013 * * * \\
(0.003)\end{array}$ \\
\hline \#Observations & 1572 & 1584 & 1539 & 1503 & 1620 & 1134 & 1081 & 1616 & 1616 \\
\hline \#Countries & 81 & 82 & 82 & 81 & 82 & 56 & 55 & 82 & 82 \\
\hline \#Instruments & 41 & 40 & 40 & 40 & 38 & 41 & 41 & 38 & 121 \\
\hline Hansen $J$-test & 0.168 & 0.140 & 0.138 & 0.140 & 0.141 & 0.221 & 0.147 & 0.163 & 0.894 \\
\hline $\mathrm{AR}(1)$ & 0.003 & 0.007 & 0.011 & 0.000 & 0.007 & 0.000 & 0.000 & 0.008 & 0.001 \\
\hline $\operatorname{AR}(2)$ & 0.935 & 0.825 & 0.749 & 0.765 & 0.831 & 0.650 & 0.568 & 0.729 & 0.907 \\
\hline
\end{tabular}

\footnotetext{
Notes: See Table 1. Robust standard errors are in parentheses; significance levels at which the null hypothesis is rejected: ***, $1 \%$; $* *, 5 \%$, and *, 10\%. The one-step difference-GMM estimator is employed in all estimations. The lagged dependent regressor is treated as endogenous (in regression 9 the economic, financial and political risk rating variables are also treated as endogenous); their lagged values and the other explanatory variables are used as instruments in the first-difference equation; they were collapsed to avoid the problem of having too many instruments. The Hansen $J$-test reports the $p$-value for the null hypothesis of instrument validity. The values reported for $\operatorname{AR}(1)$ and $\operatorname{AR}(2)$ are the $p$-values for first and second order auto-correlated disturbances in the first differences equations.
} 
Table 3. Frequency of elections

\begin{tabular}{|c|c|c|c|c|c|c|c|c|}
\hline & \multicolumn{4}{|c|}{ Average frequency of all countries } & \multicolumn{4}{|c|}{ Average frequency of OECD countries } \\
\hline & $<3.8 \mathrm{yrs}$ & $>3.8 \mathrm{yrs}$ & Elect3.8 & Timing3.8 & $<3.4 \mathrm{yrs}$ & $>3.4 \mathrm{yrs}$ & Elect3.4 & Timing3.4 \\
\hline & (1) & (2) & (3) & (4) & (5) & (6) & (7) & $(8)$ \\
\hline L.HDI_gr & $\begin{array}{c}0.308 * \\
(0.187)\end{array}$ & $\begin{array}{c}0.365 * * * \\
(0.124)\end{array}$ & $\begin{array}{c}0.377 * * * \\
(0.096)\end{array}$ & $\begin{array}{c}0.431 * * * \\
(0.097)\end{array}$ & $\begin{array}{c}0.578 * * * \\
(0.081)\end{array}$ & $\begin{array}{c}0.333 * * * \\
(0.115)\end{array}$ & $\begin{array}{c}0.377 * * * \\
(0.096)\end{array}$ & $\begin{array}{c}0.430 * * * \\
(0.097)\end{array}$ \\
\hline Elect_yr & $\begin{array}{c}0.049 \\
(0.034)\end{array}$ & $\begin{array}{c}0.070 * * \\
(0.035)\end{array}$ & & & $\begin{array}{c}0.026 \\
(0.023)\end{array}$ & $\begin{array}{c}0.077 * * \\
(0.038)\end{array}$ & & \\
\hline Elect $*$ MoreFreq & & & $\begin{array}{c}0.045 \\
(0.034)\end{array}$ & & & & $\begin{array}{c}0.025 \\
(0.020)\end{array}$ & \\
\hline Elect $*$ LessFreq & & & $\begin{array}{c}0.067 * * \\
(0.034)\end{array}$ & & & & $\begin{array}{c}0.075 * * \\
(0.038)\end{array}$ & \\
\hline Diff_ElectFreq & & & $\begin{array}{l}-0.022 \\
(0.048)\end{array}$ & & & & $\begin{array}{l}-0.050 \\
(0.041)\end{array}$ & \\
\hline Timing $*$ MoreFreq & & & & $\begin{array}{c}0.033 \\
(0.032)\end{array}$ & & & & $\begin{array}{c}0.007 \\
(0.027)\end{array}$ \\
\hline Timing *LessFreq & & & & $\begin{array}{c}0.097 * * * \\
(0.032)\end{array}$ & & & & $\begin{array}{c}0.094 * * * \\
(0.032)\end{array}$ \\
\hline Diff_TimingFreq & & & & $\begin{array}{l}-0.064 \\
(0.042)\end{array}$ & & & & $\begin{array}{c}-0.087 * * \\
(0.039)\end{array}$ \\
\hline \# Observations & 749 & 867 & 1616 & 1539 & 410 & 1126 & 1616 & 1539 \\
\hline \# Countries & 32 & 50 & 82 & 82 & 21 & 61 & 82 & 82 \\
\hline \# Instruments & 40 & 40 & 41 & 41 & 40 & 40 & 41 & 41 \\
\hline Hansen $J$-test & 0.272 & 0.420 & 0.148 & 0.138 & 0.883 & 0.391 & 0.154 & 0.139 \\
\hline $\mathrm{AR}(1)$ & 0.074 & 0.000 & 0.007 & 0.011 & 0.000 & 0.019 & 0.007 & 0.011 \\
\hline $\operatorname{AR}(2)$ & 0.632 & 0.794 & 0.808 & 0.764 & 0.896 & 0.839 & 0.822 & 0.739 \\
\hline
\end{tabular}

Table 4. Advanced economies, income and human development

\begin{tabular}{|c|c|c|c|c|c|c|c|c|c|}
\hline & \multicolumn{3}{|c|}{ OECD vs Non-OECD countries } & \multicolumn{3}{|c|}{ High vs Low Income countries } & \multicolumn{3}{|c|}{ High vs Low HDI countries } \\
\hline & OECD & NonOECD & Dummy & HIC & LIC & Dummy & HHDIC & LHDIC & Dummy \\
\hline & $(1)$ & $(2)$ & (3) & (4) & (5) & (6) & (7) & $(8)$ & (9) \\
\hline L.HDI_gr & $\begin{array}{c}0.398 * * * \\
(0.063)\end{array}$ & $\begin{array}{c}0.395 * * * \\
(0.118)\end{array}$ & $\begin{array}{c}0.378 * * * \\
(0.096)\end{array}$ & $\begin{array}{c}0.499 * * * \\
(0.059)\end{array}$ & $\begin{array}{c}0.322 * * * \\
(0.123)\end{array}$ & $\begin{array}{c}0.380 * * * \\
(0.095)\end{array}$ & $\begin{array}{c}0.515 * * * \\
(0.066)\end{array}$ & $\begin{array}{c}0.316^{* * *} * \\
(0.120)\end{array}$ & $\begin{array}{c}0.381 * * * \\
(0.095)\end{array}$ \\
\hline Elect_yr & $\begin{array}{c}0.008 \\
(0.018)\end{array}$ & $\begin{array}{c}0.099 * * \\
(0.046)\end{array}$ & & $\begin{array}{c}0.008 \\
(0.017)\end{array}$ & $\begin{array}{c}0.116^{* *} \\
(0.053)\end{array}$ & & $\begin{array}{c}0.010 \\
(0.018)\end{array}$ & $\begin{array}{c}0.111 * * \\
(0.050)\end{array}$ & \\
\hline Elect ${ }^{*} O E C D$ & & & $\begin{array}{c}0.016 \\
(0.018)\end{array}$ & & & & & & \\
\hline Elect $*$ NonOECD & & & $\begin{array}{c}0.094 * * \\
(0.045)\end{array}$ & & & & & & \\
\hline Diff_OECD & & & $\begin{array}{l}-0.078 * \\
(0.047)\end{array}$ & & & & & & \\
\hline Elect $* H I C$ & & & & & & $\begin{array}{c}0.017 \\
(0.015)\end{array}$ & & & \\
\hline Elect $*$ LIC & & & & & & $\begin{array}{c}0.116 * * \\
(0.056)\end{array}$ & & & \\
\hline Diff_IC & & & & & & $\begin{array}{l}-0.099 * \\
(0.056)\end{array}$ & & & \\
\hline Elect $* H H D I C$ & & & & & & & & & $\begin{array}{c}0.015 \\
(0.016)\end{array}$ \\
\hline Elect $*$ LHDIC & & & & & & & & & $\begin{array}{c}0.109 * * \\
(0.052)\end{array}$ \\
\hline Diff_HDIC & & & & & & & & & $\begin{array}{l}-0.094^{*} \\
(0.053) \\
\end{array}$ \\
\hline \# Observations & 837 & 779 & 1616 & 924 & 692 & 1616 & 892 & 720 & 1616 \\
\hline \# Countries & 34 & 48 & 82 & 41 & 41 & 82 & 37 & 45 & 82 \\
\hline \# Instruments & 40 & 40 & 41 & 40 & 40 & 41 & 40 & 40 & 41 \\
\hline Hansen $J$-test & 0.418 & 0.206 & 0.146 & 0.239 & 0.405 & 0.146 & 0.212 & 0.306 & 0.155 \\
\hline $\mathrm{AR}(1)$ & 0.000 & 0.024 & 0.007 & 0.000 & 0.033 & 0.007 & 0.000 & 0.030 & 0.007 \\
\hline $\mathrm{AR}(2)$ & 0.681 & 0.880 & 0.797 & 0.973 & 0.961 & 0.817 & 0.681 & 0.844 & 0.809 \\
\hline
\end{tabular}

Notes: See Tables 1-3 and respective notes; see also Table A.1 in Annex. The results for the additional covariates are not reported here to save space, but they are available upon request. 
Table 5. Presidential systems, plurality systems and proportional representation

\begin{tabular}{|c|c|c|c|c|c|c|c|c|c|}
\hline & \multicolumn{3}{|c|}{ Presidential vs Non-Presidential } & \multicolumn{3}{|c|}{ Plurarily vs Non-Plurality } & \multicolumn{3}{|c|}{ Prop.Representation vs Non-PR } \\
\hline & Presid & NonPresid & Dummy & Plural & NonPlural & Dummy & PR & NonPR & Dummy \\
\hline & $(1)$ & (2) & (3) & (4) & $(5)$ & (6) & (7) & $(8)$ & (9) \\
\hline L.HDI_gr & $\begin{array}{l}0.229 * \\
(0.119)\end{array}$ & $0.472 * * *$ & $0.377 * * *$ & $0.342 * * *$ & $0.433 * *$ & $\begin{array}{c}0.376 * * * \\
(0.097)\end{array}$ & $\begin{array}{c}0.490 * * * \\
(0106)\end{array}$ & $\begin{array}{l}0.183 \\
(0.142)\end{array}$ & $\begin{array}{c}0.375 * * * \\
(0097)\end{array}$ \\
\hline Elect_yr & $\begin{array}{l}0.061 * \\
(0.032)\end{array}$ & $\begin{array}{c}0.045 \\
(0.034)\end{array}$ & & $\begin{array}{c}0.059 \\
(0.039)\end{array}$ & $\begin{array}{l}0.041^{*} \\
(0.023)\end{array}$ & & $\begin{array}{l}0.057 * * \\
(0.029)\end{array}$ & $\begin{array}{c}0.043 \\
(0.049)\end{array}$ & \\
\hline Elect*Presid & & & $\begin{array}{l}0.062 * \\
(0.036)\end{array}$ & & & & & & \\
\hline Elect*NonPresid & & & $\begin{array}{l}0.049 \\
(0.033)\end{array}$ & & & & & & \\
\hline Diff_Presid & & & $\begin{array}{c}0.014 \\
(0.046)\end{array}$ & & & & & & \\
\hline Elect*Plural & & & & & & $\begin{array}{c}0.060 \\
(0.040)\end{array}$ & & & \\
\hline Elect $*$ NonPlural & & & & & & $\begin{array}{l}0.049 * * \\
(0.023)\end{array}$ & & & \\
\hline Diff_Plural & & & & & & $\begin{array}{c}0.011 \\
(0.044)\end{array}$ & & & \\
\hline Elect $* P R$ & & & & & & & & & $\begin{array}{c}0.055 * * \\
(0.027)\end{array}$ \\
\hline Elect*NonPR & & & & & & & & & $\begin{array}{l}0.052 \\
(0.058)\end{array}$ \\
\hline Diff_PR & & & & & & & & & $\begin{array}{c}0.003 \\
(0.062) \\
\end{array}$ \\
\hline \# Observations & 771 & 844 & 1615 & 857 & 754 & 1611 & 1308 & 304 & 1612 \\
\hline \# Countries & 46 & 36 & 82 & 46 & 35 & 81 & 62 & 19 & 81 \\
\hline \# Instruments & 40 & 40 & 41 & 40 & 40 & 41 & 40 & 17 & 41 \\
\hline Hansen $J$-test & 0.308 & 0.251 & 0.149 & 0.175 & 0.206 & 0.143 & 0.212 & 0.262 & 0.141 \\
\hline AR(1) & 0.000 & 0.050 & 0.007 & 0.047 & 0.001 & 0.007 & 0.022 & 0.006 & 0.006 \\
\hline $\mathrm{AR}(2)$ & 0.954 & 0.853 & 0.798 & 0.347 & 0.075 & 0.798 & 0.139 & 0.387 & 0.800 \\
\hline
\end{tabular}

Notes: See Tables 1-4; see also Table A.1 in Annex. In regression (8) instruments for the dependent variable are collapsed and reduced to a maximum of 7 lags. The results for the additional covariates are not reported here to save space, but they are available upon request. 
ANNEX

Table A1.Descriptive Statistics

\begin{tabular}{|c|c|c|c|c|c|}
\hline & Obs. & Mean & Std.Dev. & Min. & Max. \\
\hline$H D I$ & 4160 & 0.635 & 0.172 & 0.192 & 0.950 \\
\hline$H D I \_g r$ & 4025 & 0.799 & 0.887 & -7.646 & 13.512 \\
\hline Elect_yr & 2380 & 0.257 & 0.437 & 0 & 1 \\
\hline TimingElect & 2242 & 0.642 & 0.281 & 0.091 & 1 \\
\hline GovLeft & 1924 & 0.354 & 0.478 & 0 & 1 \\
\hline GovRight & 1881 & 0.504 & 0.501 & 0 & 1 \\
\hline GovMaj & 2337 & 0.743 & 0.437 & 0 & 1 \\
\hline GovCoal & 2372 & 0.566 & 0.496 & 0 & 1 \\
\hline MajCoal & 2331 & 0.426 & 0.495 & 0 & 1 \\
\hline Maj\% & 2354 & 57.711 & 15.101 & 9.278 & 100 \\
\hline EcoRating & 3778 & 33.780 & 7.180 & 0 & 50 \\
\hline FinRating & 3778 & 34.698 & 8.675 & 4 & 50 \\
\hline PolRating & 3778 & 64.303 & 15.146 & 9 & 97 \\
\hline CompRating & 3778 & 66.435 & 13.737 & 14 & 96 \\
\hline Corruption & 3795 & 3.004 & 1.354 & 0 & 6 \\
\hline Democracy & 2824 & 3.473 & 6.910 & -10 & 10 \\
\hline GovSize & 2407 & 5.708 & 1.548 & 1.237 & 9.934 \\
\hline Pop_gr & 5241 & 1.665 & 1.529 & -6.343 & 17.625 \\
\hline Time & 5447 & 28.081 & 9.978 & 1 & 34 \\
\hline
\end{tabular}

Notes: Data for 182 countries over the period 1980-2013; Due to missing values for some variables, the number of countries used in the estimations is reduced to 82. Those countries are: Albania, Algeria, Argentina, Australia, Austria, Belgium, Bolivia, Botswana, Brazil, Bulgaria, Canada, Chile, Colombia, Costa Rica, Croatia, Cyprus, Czech Republic, Denmark, Dominican Republic, Ecuador, El Salvador, Estonia, Finland, France, Gambia, Germany, Ghana, Greece, Guatemala, Honduras, Hungary, Iceland, India, Ireland, Israel, Italy, Jamaica, Japan, Korea, Latvia, Luxembourg, Malawi, Mali, Malta, Mexico, Moldova, Mozambique, Netherlands, New Zealand, Nicaragua, Niger, Nigeria, Norway, Pakistan, Papua New Guinea, Paraguay, Peru, Philippines, Poland, Portugal, Romania, Russia, Senegal, Sierra Leone, Slovak Republic, Slovenia, South Africa, Spain, Sri Lanka, Sweden, Switzerland, Thailand, Trinidad and Tobago, Turkey, Uganda, Ukraine, United Kingdom, United States, Uruguay, Venezuela, and Zambia.

Sources: The data for HDI comes from the Human Development Report, United Nations Development Program 2014 (http://hdr.undp.org/en/data). The political variables were obtained from the Database of Political Institutions 2012, World Bank (http://www.worldbank.org) and Comparative Political Data Set I 2013 (http://www.cpds-data.org/). The Rating and Corruption variables come from the International Country Risk Guide (http://www.prsgroup.com). Democracy is the 'polity2' variable in the Polity IV Database. The GovSize is the 'fi sog' index in the Economic Freedom of the World, Fraser Institute, (http://www.freetheworld.com/). The data for Pop_gr comes from the World Development Indicators, World Bank (http://data.worldbank.org/). 